\title{
Sexuality and Space: Tokyo and Karuizawa in Mariko Koike's Koi
}

\section{MINA QIAO}

University of Auckland

\section{ABSTRACT}

This article employs Koike Mariko's novel Koi [1995] as a case study to explore the functions of urban space in contemporary Japanese fiction. It examines the way that urban space works as an axis upon which the characters in Koi interact, and analyses how those interactions function in direct proportion to the nature of the urban space through which they move. This article also analyses the plot paradigm of 'sexual deviance/transgression during periods of social turbulence', and identifies the interrelations between sexuality and socio-political factors. The representation of urban space in Koi, together with the socio-political backdrop of the 1970s student movements, is shown to complement the construction and development of the characters' sexualities, thereby enriching the narrative and supporting Ai Maeda's claim of urban space's impact on literature.

\section{KEYWORDS}

Ai Maeda; contemporary; criminality; literature; Mariko Koike;

sexuality; urban space
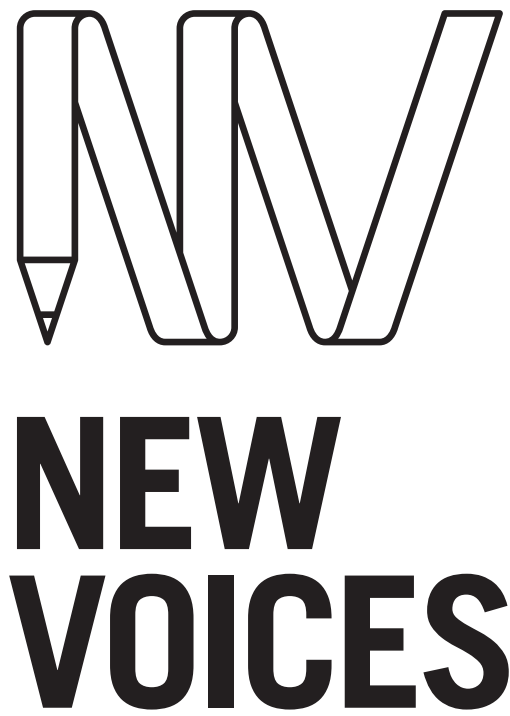

IN JAPANESE STUDIES

\section{JAPANFOUNDATION \& BRINGING JAPAN TO YOU}

To link to this article: http://dx.doi.org/10.21159/nvjs.07.02

\section{ISSN 2205-3166}

New Voices in Japanese Studies is an interdisciplinary, peer-reviewed journal showcasing the work of emerging scholars from Australia and New Zealand with research interests in Japan.

All articles can be downloaded free at newvoices.org.au

(C) The Japan Foundation, Sydney and Mina Qiao, 2015

\section{(c) $(9)$}

This work is licensed under a Creative Commons Attribution-NonCommercialNoDerivatives 4.0 International License. 


\section{INTRODUCTION}

Urban space has become an essential element of modern literature. Ai Maeda (1996) suggests that, with the frequent appearances of toponyms in literature, urban space in real life and in textual imagery infiltrate each other to generate more text in turn $(1996,24-25)$. As such a work, Koi (恋) by Mariko Koike, first published in 1995, is 'a tale of two cities'-Tokyo and Karuizawa-where an unconventional romance takes place against the backdrop of the 1970s student movements. The title, "Koi", is a Japanese word that means affection, emotional dependency, or longing.

Mariko Koike [b. 1952] is a Japanese female author. Koike was active in street demonstrations of the student movement in the late 1960s and the early 1970s, and infuses the sentiments of that era into her writing. Her trademark novels are love stories with a nostalgic flair, such as Mubansō (無伴奏 [A Cappella]; 1990) and Koi (2008 [1995]). The novel Koi won the Naoki Prize in 1996, and has also been adapted into a TV film by Tokyo broadcaster TBS ${ }^{1}$ which was first televised on December 16, 2013. The narrative of Koi is set in the context of the early 1970s student movements and the Asama Sansō Incident of 1972. ${ }^{2}$ Fumiko Yano, a university student from a working-class background, becomes an assistant to university professor Shintarō Katase for his translation project of a fictional British novel called Rose Salon. ${ }^{3}$ Fumiko is later drawn into the upper-class social circle of Shintarō and his aristocratic wife Hinako, and is captivated by their uninhibited charm. As a threesome, they become absorbed in a realm of erotic sensation while the outside world faces upheaval. The story ends when, in a strange turn of fate, Fumiko murders Hinako's new lover on February 28, 1972, the same day that the Asama Sansō Incident tragically ends.

Despite the rich elements of its narrative, Koi has attracted little scholarly attention in Japan or elsewhere. I intend to address this gap in research by employing Koi as a case study to investigate the implications of urban space in Japanese contemporary fiction. I explore the hypothesis that urban space serves as an axis upon which the characters in Koi interact, and show how the characters function in direct relation to the nature of the space in which they are located. Furthermore, I will use Koi to exemplify the plot paradigm of 'sexual transgression during periods of social turbulence' in literary works, and to identify the interrelations between sexuality and socio-political factors. ${ }^{4}$

1 Tokyo Broadcasting System Holdings, Inc.

2 On February 19, 1972, five armed members of the United Red Army broke into a lodge called Asama Sansō at Mount Asama, and took several hostages. The standoff between police and the United Red Army members lasted ten days. On February 28, the incident ended with the police storming the lodge and successfully rescuing the hostages. This incident led to the decline in popularity of leftist movements in Japan. As Koike writes in Koi, it also marked the end of an era $(2008,310)$.

3 Rose Salon is a crucial narrative device for Koi, as its translation and publication runs throughout the story. Furthermore, the novel Rose Salon serves as the mise en abyme of Koi. 'Mise en abyme' is a concept first proposed by André Gide in 1893 (Dallenbach 1989, 7), and means "an internal duplication of the theme of a work of art" that reflects the work and confirms its overall structure (Ireland 1983, 66). The surrealistic setting of Rose Salon mirrors Karuizawa's nature as a fantasyland, a 'Rose Salon' for the threesome. In this article, "Rose Salon" refers to the novel, while "Rose Salon" refers to Karuizawa as a metaphor.

4 In this article, 'sexual transgression' is defined as sexual acts that differ "in degrees of tolerance within and between societies in spite of the codes of sexual propriety sanctioned by official scientific or state discourse" 
While sexuality functions as a key motif in Koi and informs the narrative, there are also other important narrative elements. I suggest that urban space-in all its socio-political, chronological and geographical senses-is important to the representation of sexuality which drives the narrative in Koi. I identify three elements which are interrelated with social factors to facilitate the development of the narrative: modern urban spaces; the dynamic in gender relations brought about by the ménage à trois between Fumiko and the Katases; and the sociopolitical backdrop. Drawing on these elements, I explore the intersection of geographical, chronological, sociological, political and psychological elements as they contribute to the construction of sexuality in the novel.

There are three main limitations to address in this study. First, unlike Tokyo, Karuizawa is not a major metropolitan area; it is a resort town in the Kitasaku District of Nagano Prefecture, a highland area in central Japan. However, over the course of Koi, the narrative directly contrasts Tokyo and Karuizawa, positioning the sites as mirror images of each other. This study therefore regards Karuizawa as a metaphoric urban site existing in parallel with Tokyo for comparative analysis. Second, I analyse Tokyo and Karuizawa as two locations presenting opposing characteristics, and suggest that the clear dichotomy of Tokyo (culture) and Karuizawa (nature) exists to reinforce the representation of urban space in Koi. Some may argue from an urban sociological perspective that a city can never be purely 'cultural' or 'natural'. Erik Swyngedouw (1996), for example, considers cities as hybrid forms and states: "In the city, society and nature, representation and being, are inseparable, integral to each other, infinitely bound up; yet, simultaneously, this hybrid socio-natural 'thing' called 'the city' is full of contradictions, tensions and conflicts" (66). However, Koi simultaneously emphasises and leaves out certain characteristics of Tokyo and Karuizawa to enhance the tone of the narrative. These locations are artistically fictionalised to enable the storytelling. Third, Tokyo in the early 1970s has been analysed here as a city which is not liberated but actually quite conservative. Present-day Tokyo is a modern city where various kinds of subcultures take root. Tokyo is depicted as bizarre and mysterious in many contemporary films and literary works that include sexuality as a major element; for example, the Ryū Murakami novel Topāzu (トパーズ [Tokyo Decadence]; 1988) and subsequent film (1992), and the Hitomi Kanehara novel Hebi ni Piasu (蛇にピアス [Snakes and Earrings]; 2003) and subsequent film (2008). However, the interpretation of Tokyo that is adopted in this study focuses on its identity as a political capital in a time of social upheaval, and is specific to the time of the 1970s student movements which act as the backdrop for Koi.

\section{MODERN URBAN SPACE}

\section{Uptown Girl}

"Class, as with sexualities, is geographically produced" (Binnie 2011, 24). In $K o i$, urban space affects the dichotomies of central/peripheral, public/private, proletariat/bourgeoisie, and reality/fantasy. It can be argued that in Koi, Tokyo represents the proletariat and Karuizawa represents the bourgeoisie. Each site is defined by human activities and consciousness (Donald 1999, 2-3). Tokyo 
functions as the political capital of the nation, spinning at high speed while also serving as a target for activists to initiate social changes. Karuizawa, by contrast, is an upscale summer resort town located in the mountains, and is free of Tokyo's social and political strife. In this instance, "the city is, by nature, unnatural" because its landscape and even its weather are shaped by human activities $(1999,2)$. While the "unnatural" attributes of Tokyo are obvious, Karuizawa-specifically chosen for its highland characteristicswas nonetheless also built as an artificial summer retreat for the pleasure of aristocrats and elites in the political and business world (Koike 2008, 162). In other words, Karuizawa is a place for the upper classes. To the characters in Koi, moreover, Karuizawa is a getaway not only to escape the summer heat but also from Tokyo itself. While Tokyo is filled with propaganda brochures and the inflammatory speeches of leftist university students, the wealthy upper classes enjoy their leisure time in the cool breezes of Karuizawa. Stallybrass and White (1986) note that "the logic of identity-formation involves distinctive associations and switching between location, class and the body" (25), and it is clear that as Fumiko moves from one location to another, her identity undergoes a subtle transformation.

At the time of the narrative, Tokyo is a space for the masses, while Karuizawa is a private place exclusive to aristocrats and elites (Koike 2008, 162). This recalls Ai Maeda's concepts of exteriority/the world of everyday life, and interiority/the world of the non-daily:

The two realms of 'exteriority' (omote) and 'interiority' (ura), which separate the spaces of a dwelling, shift at the level of urban space into conflicting structures of the world of everyday life and the world of the non-daily. The world of the non-daily is equivalent to the interiority of a dwelling. It exhibits the negative properties that have been expelled from the world of everyday life, such as strong taboos, subtle ambiguities, anarchy, uncleaniness, marginality, and somatic sensation. ${ }^{5}$ (Maeda 1996, 68)

In Koi, Karuizawa represents 'interiority' and the world of the non-daily, which enables sensational indulgence and transgression, while Tokyo represents 'exteriority' and the world of everyday life, which stands for accepted social norms. The Katases' resort in Karuizawa is a summer house away from their work duties and social routines. Compared to the 'exteriority' of Tokyo, Karuizawa is a secretive and inviting 'interior' space where 'Other' patterns of sexuality simmer. Maeda suggests that class boundaries can be found laid between a central region and a marginal region $(1996,286)$. In Koi, the Karuizawa periphery is the heartland of the mysterious and alluring, and where class boundaries are crossed.

In The Politics and Poetics of Transgression (1986), Stallybrass and White point out the psychological dependence of the high class on the low. Without the social opposite of the excluded Others, the construction of the high's 
subjectivity is incomplete $(1986,5)$. While Fumiko's romantic affair with the Katases may appear incidental, it is also inevitable because of her status as a low Other to the Katases' high. Hinako has had other lovers who come from the upper class, such as Soejima (a businessman) and Handa (a university student), and presumably there are more, but the Katases do not make any of them a special partner as they do with Fumiko. Perhaps tired of their highclass toys, they specifically choose the marginalised and eroticised OtherFumiko-to fulfil their fantasy. Fumiko, a socially peripheral character, becomes symbolically central to this romantic affair and to the narrative as a whole in a manner that confirms these ideas:

A recurrent pattern emerges: the 'top' attempts to reject and eliminate the 'bottom' for reasons of prestige and status, only to discover, not only that it is in some way frequently dependent upon the low-Other...but also that top includes the low symbolically, as a primary eroticized constituent of its own fantasy life. The result is a mobile, conflictual fusion of power, fear, and desire in the construction of subjectivity: a psychological dependence upon precisely those others which are being rigorously opposed and excluded at the social level. It is for this reason that what is socially peripheral is so frequently symbolically central.

(Stallybrass and White 1986, 5)

In Poison Woman (2007), Christine Marran refers to Stallybrass and White (1986) and suggests that transgression (i.e., crime committed by socially peripheral parties) is embedded in the psychological dependence of the high on the low: "The trouble with transgression is indeed its indispensability. The social symbolic needs its criminals. It needs its terrorists, its sex addicts, its drug czars" (2007, xix). From this perspective, Fumiko's later crime (i.e., murdering Hinako's lover, Ōkubo) is as inevitable as her romantic affair with the Katases.

\section{The Citizen}

Caught between two places, Fumiko says to Shintarō "Welive in different worlds (生きてる世界が違うんです)”, referring to the gap between them created by class (Koike 2008, 107). If not for the Katases, Fumiko would never have come to Karuizawa to spend the summer (see 2008, 162). Even had she been able to afford the financial expense, the word 'Karuizawa' itself was sensitive for the majority of university students at a time of such political tension, and when young people enjoyed the privilege of mocking the lifestyles of the upper class $(2008,162)$. Even before Fumiko traverses the boundary into Karuizawa, she is in fact something of a drifter in Tokyo and does not seem to belong to either place. Although she comes from a university which is famous for its student movement, she never appears to care about the riots in Tokyo. Nonetheless, while she spends the summer vacation in Karuizawa, she is still merely a temporary guest in the world of the upper class. Fumiko is therefore neither a complete stranger nor a fully accepted citizen of either Tokyo or Karuizawa. 
Raymond Williams argues that "[a]n effective awareness of social identity depends on actual and sustained social relationships" (cited in Donald 1999, 154). James Donald also suggests that the identity of a "citizen" is "a position in the set of formal relations defined by democratic sovereignty" rather than "a type of person" $(1996,174)$. The romantic relationship Fumiko develops with the Katases is the basis for her temporary identity as a Karuizawa citizen/insider. Discussing the relationship between romantic bonds and identity, Gaylin notes how the former "[fuses] the separate sense of self into a common identity" (cited in Murakami 2002, 129), which in turn reinforces the notion of 'insider' and 'outsider' (Murakami 2002, 129). It is Fumiko's romantic relationship with the Katases that makes her an insider and grants her residency in Karuizawa. Moreover, according to Murakami (2002), modern emotion/desire plays two roles, namely "identification with the same and discrimination against others" (128). The logic of Otherness in urban life "often is played out in violent modes of exclusion or in isolating forms of disconnection and strangeness" (Tonkiss 2005, 28). When Karuizawa, home to three insiders (i.e., Shintarō, Hinako, and their 'pet' Fumiko), is invaded by the stranger/outsider Ōkubo, the danger of violence (i.e., Fumiko killing Ōkubo) takes root.

When the Katases' marriage is threatened by Hinako's affair with Ōkubo, the delicate balance between Shintarō, Hinako and Fumiko is also broken. On a symbolic level, the home that once belonged to the Katases in Karuizawa is now occupied by the invader, Okubo. Fumiko is no longer welcome there. The marriage of the Katases is threatened and Fumiko loses the subject of her emotional submission (i.e., the Katases as an entity), which again shows that Fumiko's identity is loosely constituted and dependent on the romantic bonds of the threesome. The deteriorating situation causes Fumiko to lose her identity and thus her free pass to this utopia. In other words, the withdrawal of Fumiko's sponsors results in her deportation from the Karuizawa fairyland. Reflecting on her crime, Fumiko mentions L'Étranger [1942], a novel by Albert Camus in which the protagonist, Meursault, kills a man for no good reason: "It is possible for people to kill others just like Meursault did (人はムルソーの ように人を殺すことができる)” (Koike 2008, 415-16). The allusion to L'Étranger may imply that Fumiko has become a stranger/outsider to the Katases and the exclusive world. This loss further compromises Fumiko's identity and leads to her violent behaviour.

\section{The Spell of Fairyland}

A fairyland requires borders because magical wonders always entail danger. The boundaries are considered to be "the separation of objects, people or places", which are "always shadowed by the idea-the 'fantasy' or the dangerof their connection" (Tonkiss 2005, 31). In Koi, Usui Pass is the border which separates Tokyo as reality from Karuizawa as fantasy. The mist in Karuizawa marks the entry into the other world. Like the fog in Dickens' London and the snow in Joyce's Dublin, the mist in Karuizawa is an inseparable part of the town's 'urban' landscape and also an externalisation of the characters' consciousness (Donald 1999): 
Once we passed Usui Pass, and before we could take a breather, there poured the inopportune rain. The dense mist, like enveloping white smoke, crept over the ground. I remembered getting an unusual vibe as if I were stepping into a strange land when the car took the path towards the villa from the highway. ${ }^{6}$ (Koike 2008, 166)

The mist, in other words, reinforces the mythical and enigmatic atmosphere of Karuizawa, while also profiling its capricious and whimsical feminine sexuality (the engendered aspect of urban space is discussed in detail later).

Hinako has many lovers; however, her taste for lovers changes with the switch of geographical locations. In Tokyo, she has a physical relationship with Handa. In Karuizawa, she loses her interest in Handa and turns to Soejima, for whom she has no feelings in Tokyo.

That person [Soejima] lives in Tokyo, and only comes here occasionally. But I feel nothing when I meet him in Tokyo. Isn't it uncanny? I fall for him every time I come to Karuizawa. It's like I am tempted. If there was something to blame, it must be the weather here.

(Koike 2008, 171-72)

Tokyo and Karuizawa are contrasted in Hinako's words, just like the two lovers: a young university student and a sophisticated middle-aged man. The two cities represent different patterns of desire, demonstrating how the landscape has an effect on the character's (sub)consciousness. From this perspective, the narrative renders the climate of Karuizawa as sensual: "Soundlessly as usual, the mist enveloped the ground and wrapped the heels of the two men. [...] Their voices were muffled and submerged in the mist (相変わらず音もなく地面 を這っている地霧が、二人の男の足元を包みこみ、…・ぐもった音と化して霧の 中に吸い込まれていった)”(2008, 176-77).

By isolating and enveloping the space of Karuizawa, the mist creates a fantastic and erotic interiority. Anthropologists such as Russell (2001) and Roche (2009) argue that marginal and private geographical settings are central to the construction of sexually transgressive action, since public conventions are replaced by negotiated norms in these contexts. The next section discusses the application of these ideas to the Koi narrative.

When a person is at a borderline, they have the potential to liberate themselves from routines of everydaylife and experience an alternativelifestyle (Yamaguchi 1975, 90). Maeda (1996) takes this idea further and suggests that, "In literary works, a character's act of crossing a border discloses his/her hidden duality and allows a glimpse of the possibilities available for living an alternative life (文学テクストに描きだされた登場人物の越境もまた彼の行為のなかに隠されてい る両義性を開示し、もうひとつの生の可能性を垣間見させる契機なのである)” (42).

Crossing the border into Karuizawa, Hinako feels she is falling in love (Koike 
2008, 173). Fumiko's emotional ties with the Katases are also developed in Karuizawa rather than in Tokyo. Karuizawa offers a seductive atmosphere and secluded space, and characters go along with this atmosphere and further contribute to it by indulging themselves in unconventional lifestyle choices. This setting serves as a prophecy in the narrative. Later on, Hinako has a lifechanging affair in Karuizawa with Ōkubo, who symbolises the dangers lurking in fantasyland which put an end to the comfort and security of the ménage à trois.

\section{GENDER RELATIONS}

\section{Outside the Salon}

Whether encoded as the relationship between the socially desirable and the pathological, the normal and the stigmatized, or the dominant subject and its dominated other, sociological studies of privilege and perversion often reinscribe the binary codes of Western epistemology.

(Ault 1996, 449)

In case studies of social norms, people whose sexual orientations, bodies and races are different from the majority often end up as socially marginalised Others. Once a norm is established, all those against the norm become Other (Clapton and Fitzgerald 1997).

In Koi, the urban dichotomy (i.e., the fictional Rose Salon as Karuizawa, versus the world outside as Tokyo) forms an essential setting. Away from Tokyo, in secluded Karuizawa, the threesome is inspired by the fictional novel Rose Salon to follow their own sexual and social norms. This enables an active female sexuality which forms the basis of the gender dynamics in Koi. The microcosm of Karuizawa, the threesome's metaphorical Rose Salon, is the centre of Fumiko and the Katases' world; yet, the 'Salon' is not a real social centre, but rather a site on the margins. The three principal characters serve as Others vis-à-vis society, and consider commonly held norms and people who espouse those norms as deviant. For example, when Hinako confesses her sexual rapacity to Fumiko-how she rushes home to have sex with Shintarō in the middle of grocery shopping-Fumiko does not think of that as at all “impure (不潔)” (Koike 2008, 251). Rather, she worships Hinako's pure and unadulterated sexual desire; Fumiko wants to be like Hinako, being able to crave carnal pleasure without any emotion (see 2008, 251). This suggests that the characters are subject to their own moral codes.

The fictional novel's eponymous Rose Salon serves as a duplication of the threesome's world. Here also, primitive sexuality is worshipped. Fumiko relates a description of Rose Salon as it appears in Rose Salon's narrative:

A group of men and women gather in the sanctum called "Rose Salon". Like heavenly deities, they live by the unfathomable rules of nature, endlessly copulating, conversing, laughing, weeping, singing and dancing.

(n)


While the Salon is not completely free of secular emotional entanglement, sentiments such as jealousy, irritation, or a sense of alienation soon disappear into the unique sexual energy of the Salon itself. It is only when a new character appears that a ripple is felt by the members of the Salon, revealing the candid dynamic of a work of fiction. When that new character blends into the Salon, however, a quiet, calm lull descends on the ground. ${ }^{8}$

(Koike 2008, 245)

As in the fictional novel, Rose Salon, sexuality is regarded as sacred in the threesome's world, while emotional and spiritual relations are regarded as profane. For Fumiko and the Katases, the ground rule is always to obey and perform in a way that places a high value on carnal pleasure, and their worship of unadulterated sexuality forms the basis of their own standard of morality. To Fumiko, the Katases are "elegant and immaculate, and above all, enormously sensual (高貴で無垢で、そのうえ、素晴らしく官能的だった)” (Koike 2008, 198). Being "enormously sensual" does not detract from but rather enhances Fumiko's perception of their nobility and innocence. For Fumiko, it is the socially desirable that is pathological, and the 'normal' that is stigmatised.

The entry of Ōkubo, however, disrupts this pattern. This is because Hinako establishes a platonic rather than carnal bond with the young man. Realising this, Fumiko begins to see Hinako as dissolute. To Fumiko, the fact that Hinako craves Ōkubo's spirit instead of his body is “filthy (不潔な行為)" (Koike 2008, 344). “[Hinako's craving for spirit] defiled human dignity. People who greedily demand flesh and sensation and indulge themselves in sex are far cleaner (污らわしかった。領欲に肉体を求め、快感を求め、性に溺れていく人 間のほうが、遥かに清潔だ、と私は思った)”(2008, 344). To Fumiko, Hinako’s pure and holy image when "she enjoyed sleeping with thousands of men other than Shintarō (信太郎以外に、千人の男を相手にし、嬉々としている)”, stands in stark contrast to the Hinako who, now having "committed her soul to only one man”, becomes “no different to a whore (たつた一人の男に魂をまるごと預 けようとする雛子は淫売も同然だった)” (2008, 344). Thus, the norm for sexual relationships in Koi, which had valorised the profane, begins to disintegrate with the appearance of Ōkubo, who refuses to conform to that paradigm.

\section{Corporeality and the Metropolis}

The body and the city are produced under the influence of each other: "the city is made and made over into the simulacrum of the body, and the body, in its turn, is transformed, 'citified,' urbanized as a distinctively metropolitan body" (Grosz 1992, 242). Urban space, therefore, is a socially constructed body to which a gender can be attributed $(1992,242)$. As the public-private and cultural-natural dichotomy conventionally corresponds to masculinefeminine space (Korsmeyer 1998, 158; Grosz 1992, 248), Karuizawa becomes 
feminised for its privacy and naturalness, and Tokyo represents masculinity for its public and cultural attributes. In this way, Koi contrasts Tokyo and Karuizawa as engendered bodies.

"The body-politic is an artificial construct which replaces the primacy of the natural body", such that the body-politic of urban space is a battle between culture and nature (Grosz 1992, 247-48). Applied to Koi, the power structure that is masculine (cultural) productivity attempts to supersede and overtake feminine (natural) reproduction $(1992,248)$. In Koi, the political protests carried out by the students in Tokyo represent masculine force: cultural, productive, and aggressive. These protests aim to overturn authority in the name of civilisation and democracy. Karuizawa, where the heart of the bourgeois class lies, thus serves as the feminine defence which represents nature and idleness. The class struggles that divide Tokyo and Karuizawa correspond to a gender combat in which each sex occupies a battlefield: male for Tokyo and female for Karuizawa.

As discussed above, the mist in Karuizawa symbolises unpredictable feminine charm. Karuizawa as a whole embodies female sexuality. The triumphs of female sexuality over the male take place in Karuizawa. Furthermore, a biblical element also becomes apparent in this relationship, as argued below.

\section{Lilith versus Adam}

According to Fumiko, "In my eyes, Hinako was Eve, and Shintarō was Adam. Even if Eve slept with hundreds of men and Adam slept with hundreds of women, they would still be the one and only couple in the world and no-one could ever come between them"9 (Koike 2008, 185). However, is Hinako really Eve? Or does her rebellious character better fit the figure of Lilith? In the chapter Genesis, Lilith is depicted as the first woman God created for Adam. However, Lilith leaves Adam because she thinks that they are equal (see Renold and Ringrose 2012). Compared to Eve, who in spite of her original sin is ultimately portrayed as submissive, Hinako has more in common with Lilith, who asserts, "I will not lie below", and who dares to desert Adam (Genesis 2:18, cited in Renold and Ringrose 2012, 48). Lilith's rejection of Adam symbolises "women robbing men of phallic potency" (Renold and Ringrose 2012, 49). In the contemporary context, mythological references remain instructive for the analysis of cultural motifs and anxieties over feminine power and masculine loss in literature (2012, 49-50). For example, in Lolita [1955] by Vladimir Nabokov, an analogy of Lilith is used to describe the sexual charm of the putative femme fatale, Lolita: "Humbert was perfectly capable of intercourse with Eve, but it was Lilith he longed for" (Nabokov 2000, 20).

Lilith is often associated with the fear of castration. Hinako's aggressive sexuality in Koi can be seen as an assertion of femininity and a challenge to male domination-in other words, a desire to castrate the male. The narrative of Koi can be interpreted as a feminist struggle against patriarchy: the battle

\section{TNAPANESE STUDIES}

.


of Lilith versus Adam, a revolution in which females claim their power. In this small-scale feminist revolution, Hinako symbolises the dominating rebel of female sexuality, and Fumiko is the loyal follower of Hinako. We have seen how Fumiko admires Hinako's sexual rapacity, and thinks that "I rather envied her for having such a high sexual drive...I wanted to be like Hinako（雛子の性欲の強さを頼もしく羡ましく思った。……私も雛子のようになり たかった)" (Koike 2008, 251). Hinako is the role model for Fumiko in terms of sexual relations.

On the other hand, Shintarō represents the symbolically castrated male, as discussed in three ways. First, Shintarōs ability to have sexual intercourse with other women is constrained by Hinako. Hinako tells Fumiko that "Shinchan is amazing. Since we got married, he hasn't slept with anyone besides me. Not even once (信ちゃんって、えらいのよ。私と結婚してから、一度も他の女 の子を抱いたことがないんだから。ただの一度もよ)” (Koike 2008, 173). From her choice of words (such as "amazing" and "not even once"), the reader sees that it is not easy for Shintarō to remain faithful to Hinako, presumably because of his attractive physical appearance (see 2008, 120). However, Hinako does not reciprocate his loyalty, maintaining overtly physical relationships with two men-one of whom is Shintarō's student. Second, the only affair Shintarō has is with Fumiko, of whom Hinako approves. After their time together, Shintarō reports the details of their intercourse to Hinako. Hinako says to Fumiko, "Shin-chan said it was great! Fū-chan was so amazing that he felt extremely aroused! (信ちゃんは、よかった、って言ってたわ。ふうちやんは素晴 らしかった、って。ものすごく興奮しちやった、って)” (2008, 220-21). The nature of Shintarō's sexual relationship with Fumiko is different from infidelity. Shintarō's sexuality is under the control of Hinako, even though he has had extramarital sex with Fumiko. Third, as the narrative unfolds, Shintarō and Hinako's biological relationship is revealed: they are half brother and sister. This is why Shintarō and Hinako do not have any children. When Fumiko asks Shintarō, “Don't you want to have children? (子供を作りたくならなかった んですか)”, Shintarō answers, "Don't you know, Fū-chan? We simply cannot, because we have never forgotten the fact that we are half brother and sister (わかるだろう?ふうちやん。僕たちが子供を作ることは許されない。その意味で、 僕たちは兄と妹であることを片時も忘れたことはなかったんだよ)” (2008, 410). However, Shintarō is unable to leave Hinako and start afresh with other women. His response to Fumiko's question about starting over with someone else is, “Too bad. That's impossible (残念だけど…..それはない)” $(2008,410)$. Their incestuous and infertile marriage can be seen as the deprival of Shintarō's phallic potency. Shintarō's male sexuality can be seen as castrated because his sexuality fails to carry out the functions of exclusiveness or fertilisation, even within his own marriage. With Hinako as the head of their polygamous household, Shintarō and Hinako's relationship and marriage are a mark of the triumph of female sexuality.

Compared to Shintarō, Ōkubo represents the uncastrated and sexually active male. If Shintarō is defeated, then Ökubo is a victorious combatant in the same battle. Ōkubo perseveres in close combat with Hinako because he is impervious to Hinako's weapon-her sexuality. Ōkubo's first meeting with 
Hinako hints that they will engage in a platonic relationship. When Ōkubo comes to the house, Fumiko and Shintarō are doing a crossword puzzle. The word Shintarō deciphers is "Platonic Love". "After the last piece of the puzzle was completed, Hinako asked the young man to the balcony. And then, they fell in 'Platonic Love' in the true meaning of those words (その言葉を最後に してクロスワードパズルが締め括られた直後、雛子はあの若者をベランダに招き 入れた。そして、文字通りの精神的な恋におちたのだ)” (Koike 2008，289). The platonic characteristic of their relationship defeats Hinako's sexuality. In the narrative, Hinako does not have sex with Ökubo in the early stages of their relationship. Hinako confesses to Fumiko about her love for Ōkubo: "My love for him does not concern the body. Nor does his love for me. Sensual pleasure soon burns out, but spiritual pleasure lasts forever (私が愛してるのは勝也の肉 体なんかじゃないの。彼が愛してくれてるのも、私の肉体じゃないの。肉体の快楽 は味わえば、すぐに消える。でも、精神の快楽は永遠に続くのよ)” $(2008,355)$. Ōkubo satisfies a more profound need than Hinako's sexual desire, while Shintarō has been indulging Hinako in purely sexual terms. After Hinako has sex with Ōkubo, she says, "Such perfect sex seemed to exist beyond this world (あれほど完壁なセックスはこの世にないと思われるくらいに)” $(2008,354)$. Ōkubo subjugates Hinako both psychologically and, eventually, physically. It seems that the male is going to win the battle at this point. However, the plot takes a turn that can be read as a subversive response to the common motif of phallocentric literary works.

\section{Hell Hath No Fury}

Modern feminists such as Simone de Beauvoir and Kate Millett draw literary critics' attention to the masculine bias in literary works (Tolan 2006, 326). The practice of approaching male authors from a feminist perspective is known as "phallocentric criticism" $(2006,326)$. Phallocentric criticism has identified patterns of imagery and language use which demonstrate concealed negative attitudes toward femininity. Feminist critics point to "the frequency with which novels punish women associated with sexuality and lust" (2006, 327). In the example of Koi, Hinako and Fumiko are the typical transgressive women with overtly sexual power who would be punished in conventional phallocentric works. The motif of "the transgressive female...eventually penalized for her action" can be found in classic literary works by male authors (e.g., Leo Tolstoy's Anna Karenina [1877] and Gustave Flaubert's Madame Bovary [1856]) $(2006,327)$. Female sexuality that attempts to challenge the dominance of male sexuality (e.g., in sexual terms by committing adultery) is punished under the patriarchal moral code in the narratives of these novels. In the narrative of Koi, too, Fumiko commits a crime and in an apparent punishment of the transgressive female serves a sentence of fourteen years' imprisonment. Nevertheless, Fumiko's behaviour can also be seen as a deliberate self-sacrifice, made in order to complete her mission. To be specific, Fumiko senses the danger to the ideals she holds dear and decides to take action when she realises that Ōkubo has defeated Hinako's sexual dominance. Fumiko's mission is to rewrite the result of the battle. The climax by means of which Fumiko takes matters into her own hands has its parallel in the decline of the student movement in the early 1970s. 
The student movement can be seen as a duplication of the feminist struggle. Both are uprisings of minorities (i.e., leftists and females) attempting to overturn the authorities (i.e., central political authority and patriarchal authority). Both struggles start out in Tokyo, where Fumiko first meets with the Katases and the student movement rages, and retreat to (and end in) Karuizawa. The switch of locations symbolises the storyline of female sexuality confronting patriarchal possession (Tokyo) and then withdrawing into its own heartland (Karuizawa). The United Red Army's last-ditch resistance at Asama Sansō mirrors the downhill trajectory of Hinako's revolution and the desperate attempt that Fumiko will make to set things 'right'.

The depiction of the Asama Sansō Incident runs through two chapters, in which Fumiko confronts and kills Ōkubo. For instance, one chapter opens with "The hostage crisis and police siege at Asama Sansō ran on every TV broadcast throughout the entire day. Viewer ratings reached $90 \%$, which was unprecedented in the history of TV broadcasting (その日は一日中、全国の $\mathrm{TV}$ 局が浅間山荘における人質救出強行作戦の模様を生放送し続け、瞬間最高 視聴率が九十パーセント近くにまではね上がった、という $\mathrm{TV}$ 史上、類を見ない日 でもあった)" (Koike 2008, 431). It is when Fumiko begins forming the idea of killing Ōkubo that the narrative mentions the TV broadcasts of the Asama Sansō Incident. This is a moment in that narrative when the historical events resonate with the characters' personal fates.

The United Red Army's killing of police at Asama Sansō and Fumiko's murder of Ökubo are similar acts-the desperate struggle of one who is cornered. In the end, Fumiko successfully eliminates Ōkubo, the uncastrated sexual male, and preserves a partial victory for female sexuality which sees Shintarō and Hinako back together. Because it is assumed that after the incident, Hinako retreats from her previous lifestyle (i.e., taking lovers, having casual sex) and becomes a carer for Shintarō who is injured in the incident and paralysed later, the feminist struggle is incomplete. Even though Fumiko eliminates Ōkubo, the ménage à trois collapses with the murder. Her professional relationship with Shintarō also ends with the publication of Rose Salon. Furthermore, the fact that Rose Salon goes out of print while Fumiko serves her time in prison symbolises the fleeting happiness of the threesome. Rose Salon is not only a living relationship between Fumiko and the Katases, but also a concrete artefact of the female dominance that had defined their relationship. From the perspective of the feminist battle against patriarchy, Shintarō's paralysis serves as a reconfirmation of his symbolic castration and status as a prisoner of war-the war to which Fumiko sacrificed herself in order to alter its outcome. Although her feminist subversion only goes halfway, the novel's ending sends out feminist messages that partially subvert the traditional phallocentric paradigm.

\section{SOCIOPOLITICAL BACKDROP}

\section{Duplication of the Riots}

In her studies of female criminality, Ann-Louise Shapiro notes that "[d]eviant women [seem] to offer a particularly vivid mirror in which to recognise the ills of modern urban life" (Shapiro 1996, 218). Fumiko's crime reflects conflict not 
only in the private sphere but also in the public sphere. In the fin-de-siècle Paris analysed by Shapiro, crimes of passion committed by women can be seen as a means of addressing social problems such as "unstable gender relations" and "perceived threats to the traditional family" $(1996,137)$. The hazards inherent in Fumiko and the Katases' unconventional interpersonal relationships and sexual practices lurk beneath the surface long before Fumiko produces the gun she uses as a murder weapon. Fumiko's 'private' crime and the public Asama Sansō Incident both function as forms of social confrontation. The two actions parallel each other and thus enrich the narrative.

On the day which altered my destiny, Japan's national attention was drawn to the news of Asama Sansō. With this news the talk of the town, I came alone to Karuizawa where the members of United Red Army were firing shots, and took up a gun in my hands. Even as my finger pulled the trigger, TV was broadcasting news of the Asama Sansō Incident. [...]

They buried one era as they clashed with the law and sacrificed several lives. And I, who was around the same age as they at that time, forfeited my future by committing the murder. ${ }^{10}$

(Koike 2008, 309-10)

The TV broadcast of the Asama Sansō Incident duplicates Ōkubo's murder scene at the Karuizawa villa. Even though Fumiko is apathetic about politics, she notes that what she has in common with the people of that era (e.g., the United Red Army, leftist students) is the fact that they are drowning in "a kind of fantasy (或る種の幻想)” $(2008,310)$. While her fantasy is about sexuality and theirs is about politics, both are social constructs. The TV footage duplicated by Fumiko's shooting confirms the subtle relations between sexuality and politics at a specific historical period. Neither social circumstances nor the political environment can be excluded from the construction of sexuality.

When fantasy is crushed by reality, Fumiko crosses a fatal boundary and a tragic public event becomes part of a private affair. Fumiko's crime and her fate are inevitably imprinted on this turbulent time of social change. Fumiko is one of the masses who are destroyed by the social elites in that era. In Shapiro's words, "In retelling [the stories of female criminality], attentive to their production, mobilisation, and effects, we can see the dense web of cultural concerns that stretched across the social distance between elite and masses, oblivious to the (rhetorical) boundaries between public and private worlds, which allowed criminal women to be the carriers of so much symbolic weight" $(1996,220)$. In other words, Fumiko serves as a scapegoat for all those who have threatened the social order during the student movements of the 1960s and the early 1970s. 


\section{Love in a Fallen City}

As suggested above, the student movement and the Asama Sansō Incident function in parallel to the main thread of Koi's narrative. Furthermore, the socio-political backdrop of the narrative is entangled with the story itself. Marran (2007) argues that deviant behaviours on the part of transgressive women appear especially in times of political and social change. Referring to Shapiro's studies of Parisian cases [1996] and Lisa Duggan's studies of American cases [2001] on female criminality, she suggests that the representation of the female sexual "deviant" and crime are inseparable from social life and that "these stories of social deviants are 'cultural narratives"” (Marran 2007, xvi). To borrow Shapiro's words, Koi is a "melodrama" which casts "deviant women in leading roles" $(1996,10)$, and it aligns with Shapiro's conclusion that "the story of female criminality [is] a story about the pain of social change" (1996, 10). Thus, in Koi, the setting of the narrative, the year 1972 (the year of the Asama Sansō Incident) and Tokyo/Karuizawa all become essential to the characters' sexual transgression, and therefore to the storytelling.

As a love story set in a time of chaos, the socio-political backdrop is the stage upon which characters act, and the socio-political conditions constrain (as well as facilitate) the characters' actions. Koi's plot paradigm of 'ménage à trois under social turbulence' can also be found in other literary works; for example, Ein Lied von Liebe und Tod (A Song about Love and Death) by Nick Barkow [1988], and Gilbert Adair's The Dreamers [2003]. Koike uses specific historical events as the background to her novel, which enriches and enables its narratives. The transgressive sexuality in $\mathrm{Ko} i$ is inseparable from the social conditions of the time of the narrative. Riots and revolutions turn society upside down and challenge existing social norms. When people's belief in norms is shaken by social change, a transgressive side of humanity is released. Thus, Tokyo and Karuizawa during the 1970s student movements become fallen cities, where transgression and deviance can appear.

\section{CONCLUSION}

Throughout Koi's narrative, modern urban space defines two distinct social classes and marks the boundary between them. Fumiko's original social identity as a peripheral character from the lower class makes her a symbol of the eroticised Other, and determines her transgression. The dichotomy of Tokyo and Karuizawa symbolises the class stances and characters' attitudes towards politics (i.e., Tokyo as lower-class people who are aggressive and radical; Karuizawa as upper-class people who are indifferent and apathetic). Fumiko, who crosses this boundary, is caught in between the identities of 'the citizen' and 'the stranger'. The instability of Fumiko's social identity leads to her deviance. The geography of Karuizawa, which offers grand natural beauty and secluded space, serves as an accelerator to the actions of the characters.

The ground rule that the threesome follows falls outside the social norms of mainstream society, which generates danger in their social relations. The 
trope of 'metropolis as corporeal' allows us to read Tokyo and Karuizawa as each having a sexual identity. The engendered metropolitan bodies of the masculine force (Tokyo) or feminine force (Karuizawa) develops the narrative of the feminist struggle against patriarchal domination. The gender relations represented in the narrative evolve around the plot of females attempting to subjugate males through symbolic castration. As analysed in this essay, the narrative of Koi utilises the historical background of political upheaval to facilitate the storytelling. The feminist struggle in pursuit of sexual fantasy duplicates the 1970s student movement in pursuit of a political one, highlighting the contrast between the sexual and the political in the narrative. At the end of the narrative, Fumiko's crime duplicates (on an individual scale) the chaos prevalent in her society. The shots she fires at the Karuizawa villa echo the gunfire at Asama Sansō. The chronological aspect of the urban space (i.e., Tokyo in the late 1960s and the 1970s, and Karuizawa at the time of the Asama Sansō Incident) provides the characters with the stage upon which they act. The elements of sexual transgression and female criminality complement the representation of urban space, and vice-versa. The narrative further weaves a socio-political element into the construction of sexuality. In sum, sexuality in $K o i$ is constructed through the entanglement of geographical, chronological, sociological, political and psychological elements.

Ko $i$ is a story about sexuality and, at the same time, a story about cities. Karuizawa in its geographical sense supports the characters' unconventional sexualities. Framing the story in Tokyo/Karuizawa during the early 1970s student movements shows the urban space in its socio-political and chronological senses, which in turn forms the thread of Koi's narrative of sexual transgression. The representation of urban space complements the construction and development of the characters' sexuality together with sociopolitical factors, and enriches and deepens the narrative with the inclusion of historical context. From the analysis of Koi's narrative, we have seen that the representation of sexual transgression necessitates the presence of social upheaval, making Koi a salient example of a literary work with the plot paradigm of 'sexual transgression during social turbulence'. The narrative of Koi also shows the significance of urban space as a literary motif in all its socio-political, chronological, and geographical senses.

\section{REFERENCE LIST}

Ault, A. 1996. "Ambiguous Identity in an Unambiguous Sex/Gender Structure: The Case of Bisexual Women." The Sociological Quarterly 37 (3): 449-63.

Binnie, J. 2011. “Class, Sexuality and Space: A Comment.” Sexuality 14 (1): 21-26.

Clapton, J. and Fitzgerald, J. 1997. "The History of Disability: A History of 'Otherness'." New Renaissance 7 (1). Accessed 2 September, 2012. http://www. ru.org/human-rights/the-history-of-disability-a-history-of-otherness.html.

Dallenbach, L. 1989. The Mirror in the Text. Chicago: The University of Chicago Press. 
Donald, J. 1996. “The Citizen and the Man About Town.” In Questions of Cultural Identity, edited by P. du Gay and S. Hall, 170-90. Trowbridge, Wiltshire: The Cromwell Press Ltd. 1999. Imagining the Modern City. Minneapolis: University of Minnesota

Press.

Donnan, H. and Magowan, F. 2009. "Sexual Transgression, Social Order and the Self." In Transgressive Sex: Subversion and Control in Erotic Encounters, edited by H. Donnan and F. Magowan, 1-24. Oxford: Berghahn Books.

Grosz, E. 1992. “Bodies-Cities.” In Sexuality and Space, edited by B. Colomina, 241-54. New York: Princeton Architectural Press.

Hebi ni Piasu [蛇にピアス]. 2008. Directed by Y. Ninagawa [蜷川 幸雄]. Tokyo: Amuse Soft Entertainment.

Ireland, K. R. 1983. "Dark Pit of the Past: Gide's Mise en abyme and Natsume Soseki's Mon." Comparative Literature Studies 20 (1): 66-76.

Kanehara, H. [金原 ひとぬ]. 2004. Hebi ni Piasu [蛇にピアス]. Tokyo: Shūeisha [集英社].

Koike, M. [小池 真理子]. 2008. Koi [恋]. Tokyo: Shinchōsha shuppan [新潮社出版]. 1990. Mubansō [無伴奏]. Tokyo: Shūeisha [集英社].

Korsmeyer, C. 1998. "Perception, Pleasure, Arts: Considering Aesthetics." In Philosophy in a Feminist Voice: Critiques and Reconstructions, edited by J. A. Kourany, 145-72. New Jersey: Princeton University Press.

Maeda, A. [前田 愛]. 1996. Toshi kūkan no naka no bungaku [都市空間のなかの文学]. Tokyo: Chikuma shobō [筑摩書房].

Marran, C. L. 2007. Poison Woman: Figuring Female Transgression in Modern Japanese Culture. Minneapolis and London: University of Minnesota Press.

Murakami, F. 2002. "Murakami Haruki’s Postmodern World." Japan Forum 14 (1): $127-41$.

Murakami, R. [村上 龍]. 1988. Topāzu [トパーズ]. Tokyo: Kadokawa shoten [角川 書店].

Nabokov, V. 2000. Lolita. London: Penguin.

Renold, E. and Ringrose, J. 2012. "Phallic Girls?: Girls” Negotiation of Phallogocentric Power." In Queer Masculinities: A Critical Reader in Education, edited by J. C. Landreau and N. M. Rodriguez, 47-67. New York: Springer Science + Business Media.

Roche, R. 2009. "A Curious Threesome: Transgression, Conservatism and Teenage Sex in the 'Free House' in Northern Ireland." In Transgressive Sex: Subversion and Control in Erotic Encounters, edited by H. Donnan and F. Magowan, 69-90. Oxford: Berghahn Books. 
Russell, A. 2001. "Teenage Pregnancy and the Moral Geography of Teesside, UK." In Managing Reproductive Life: Cross-cultural Themes in Sexuality and Fertility,

edited by S. Tremayne, 221-34. Oxford: Berghahn Books.

Shapiro, A. 1996. Breaking the Codes: Female Criminality in Fin-de-Siècle Paris. Stanford, California: Stanford University Press.

Stallybrass, P. and White, A., 1986. The Politics and Poetics of Transgression. New York: Cornell University Press.

Swyngedouw, E. 1996. "The City as a Hybrid: On Nature, Society and Cyborg Urbanization." Capitalism Nature Socialism 7 (2): 65-80.

Tolan, F. 2006. "Feminisms." In Literary Theory and Criticism: An Oxford Guide, edited by P. Waugh, 319-39. New York: Oxford University Press.

Tonkiss, F. 2005. Space, the City and Social Theory. Cambridge: Polity Press.

Topāzu [トパーズ]. 1992. Directed by R. Murakami [村上 龍]. Tokyo: JVD Co. Ltd.

Yamaguchi, M. [山口 昌男]. 1975. Bunka to ryōgisei [文化と両義性]. Iwanami shoten [岩波書店]. 